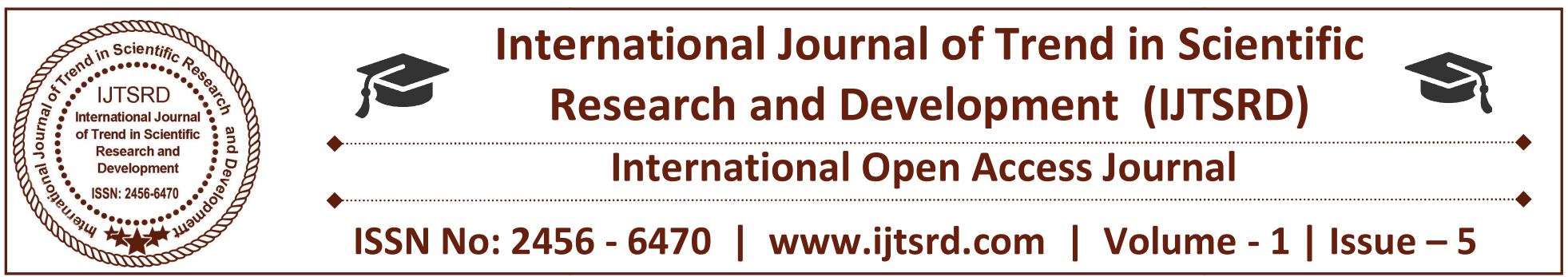

\title{
An Assessment of the use of Language in Ifeoma Okoye's Men Without Ears
}

\author{
Unubi, Sunday Abraham \\ Department of Igala Language and Culture, \\ School of Languages, Kogi State College of \\ Education, PMB 1033, Ankpa, Nigeria
}

\author{
Ikani, Eneojo Friday \\ Department of Igala Language and Culture, \\ School of Languages, Kogi State College of \\ Education, PMB 1033, Ankpa, Nigeria
}

\begin{abstract}
This research examines the artistic use of language by Ifeoma Okoye in her novel: Men Without Ears. The author uses language to admonish the Nigerian citizenry in particular and mankind in general to beware of vainglory or pride, incontinency, corruption, professional misconduct as well as undue desire for amassment of material wealth. The writers of this paper painstakingly assess such use of language by the author, and by so doing, they have not only conspicuously inflamed the passion of the readership but also added aesthetic value to the novel.
\end{abstract}

Key word: language

\section{INTRODUCTION}

The linguistic dexterity used in Men Without Ears by the author, Ifeoma Okoye, is captivating and unique, in that it simplifies the message for the readers' understanding. This is intentional on the part of the writer to portray the tragedy of conspicuous consumption or vainglory, unbridled quest for monetary and material gains, professional misconduct as well as bribery and corruption that have pervaded the Nigerian society, which are the central themes of the text.

In fact, all these are brought to limelight in one of the words of the text, "...a country where money-bags were held above men of character and where means was the measure of virtue" (153).
Some of the features that comprise the language use in the text are discussed below:

\section{TITLES/ALIASES}

Undue premium is placed on titles or epithets in the novel. This is because the characters derive pride and pleasure from these titles as they blow some cool air of importance on them. As the writer puts it, “... those in national dress made of expensive lace and brocade had epithets for names..." (24).

The most disturbing aspect of it is that even the professions that do not follow people's names are made to be so. In fact, to address one as Mr. is ridiculous. For instance, Dr. Uba becomes highly upset when Chigo addresses him simply as "Mr. Uba" (25). The same is the case when Chigo addresses Engineer Akah as "Mr. Engineer Akah" (4).

There are two kinds of titles used in the novel. Namely: professional/traditional, and hyperbolic titles.

Professional/traditional Titles: These include: "Dr" (Dr. Uba (25), "Engineer" (Engineer Akah) (4) "Chief" (Chief Ozo Kelie) (92), "Igwe" (37) "Accountant" (Accountant Chigo) and so on.

Hyperbolic Titles: Some of these are in native language. They include: "Orimili" - the sea that never gets dry, "Aka-jiaku" - the tree that bears money as its fruits, "Young Millionaire", "Ichie 
Gold", "Swiss Bank", Cash Madam", “ Madam True Money", "Bank” (21-22, 24).

\section{CODE-MIXING}

The writer's mixing of native language with English in the text is not due to inadequacy or paucity of English vocabulary to describe such words. Rather, she does this deliberately to add spice and flavor to the text. The words are: agbada (10), buba (20), obi (32), Igwe (37), ofala (42), oga (106), diabolical juju men (153), etc.

\section{ANTITHESIS}

There is the juxtaposition of contrasting ideas identified in some sentences in a balanced manner. Perhaps the writer does this in order to bring their full effect to bear on the readership. These include:

"...punctuality was anathema to the majority of workers while malingering was common" (102).

"...the average worker in the company was slothful rather than diligent" (102).

"... in my country, efficiency, scholarship and creativity were shunned while incompetence and ignorance were acclaimed" (90).

\section{OXYMORON}

The author places incongruous or contradicting terms side by side in the text. This is done to paint the picture of how morality and societal norms are sacrificed on the altar of undue quest for money and material gains in a more captivating way in the mind of the readers. An example of such is a phrase 'thrive in disorderliness' (1).

\section{PIDGIN}

The writer uses pidgin English in the text to portray the level of involvement of uneducated youth in the frenetic pursuit for unwholesome money. This is clear in the dialogue between Chigo and the airport tout: "...You de travel sir?... You don get boarding pass, sir?... I fit help you get one, sir...Just give me fifty naira, sir... You go see. Maybe you new for this place. Nobody fit give you boarding pass unless you give am money" (2).

\section{COLLOCATION}

Some words used in the text collocate or co-occur with another. Again, the author perhaps does this to emphasize the full import of the message and makes it more luminous and impacting on the readership. They include: "...they preferred to get the bereaved home by telling him an 'innocuous lie'..." (1), "What an 'ill-fated journey" (3) "...with a triumphant smile'..." (3), "...the 'mad rush' for seats on the plane" (6), "Never had I come across people so 'gorgeously overdressed" (24), "...I cannot rescue him from the "fatal plunge' he has taken..." (48), “...wearing himself out by trying to be like those men with 'false pretension' and "counterfeit appearance"" (48), "He turned to us the 'dumbfounded onlookers'..." "...he deplored the 'naira mania' which had gripped our people..." (152).

\section{IDIOMATIC EXPRESSION}

The wrter flavourfully and colourfully wields idioms into the language of the text in a simple but captivating manner. This she does with a view to driving the message home to the audience. Examples of idioms used in the text include; "I felt ill at ease as I picked my way through the chaos..." (1), "Boiling with rag, I found a quiet corner in which to nurse my anger" (2), "I was beside myself with joy" (3) "Those men and women...fought tooth and nail with the wind for their possession" (5), "Her wings must be clipped..." (44), "As long as you don't stick out your neck too far, you will be alright" (92), "...to hang his bag where he could reach it" (126), "...allowing him to stew in his own juice" (126), "Can't you for once forget what others might think or say and blaze your own trail?" (136).

\section{PROVERB}

The writer also uses proverbs to enrich the language of the text. Some of the proverbs are warning signals to Uloko, warning him of his imminent doom if he continues in his false life. Examples are: "...It is a question of those who live in glass houses being wise enough not to throw stones" (29) "Uloko has come to the land of people without ears and is bent on cutting off his ears too" (48 - 49), "the rat that joins a lizard for a frolic in the rain will remember only when it is too late that he will not dry himself easily as the lizard" (48), "... a fly who refuses to heed advice follows a corpse to the grave" (115), "All dogs eat 
shit but only those who carry some remnants of it around their mouths give themselves away (125).

\section{REPETITION}

Repetition, as it is often said, is for emphasis. The author repeats some words, phrases, clauses or parts of clauses in an interesting manner in almost similar sentences. Some of them are: "It is all because I have tried to stop him from the big chase for naira...it is all because I have tried to stop him from becoming a slave to debt" (48), "You don't seem to understand the impropriety of the thing you want me to do for you,. You don't seem to understand what you want me to do for you could ruin my career" (124), "I can't" "I just can't". It's not done", "I wished I could run away..." I wished Iruka, my fiancée, was around..." (124), "I wished I could go back to Tanzania" (125).

\section{SYMBOLISM}

The author uses symbols to appeal to the emotion of her readers. One example of this is: "The setting sun...casting a beam on his face" (132). The sun symbolizes Chigo's father; its setting symbolizes his death.

\section{IRONY}

The writer uses irony to expose certain situation in the text. For example, Young Millionaire, as his name suggests, is believed to be a man of wealth but "his children were undernourished, having protruding bellies while his steward was shabbily dressed and dirty". In addition, his "sitting-room was expensively furnished and everything in it was giantsized, but the colour combination was repulsive. The heavy curtains were a lurid yellow; the upholstered armchairs, a dirty green; and the carpet, scarlet (60$61)$.

\section{PARALLELISM}

The author arranges series of words, phrases or clauses that are related structurally to indicate how similar they are in an emphatic way. Examples of this include: "... I found the Igwe's assumed airs of superiority irritating, and his affected manner of speech nauseating" (39), "Never had I seen a person so full of himself, so puffed up by pride (85).

\section{CONCLUSION}

The language use is simple but pungent and captivating. The title of the novel: Men Without Ears is an Ibo proverb that means 'when one comes to the land of people without ears, one has to cut off one's ears too'. It refers to men like Uloko who has ears biologically but are dull of hearing. This is as good as having no ears at all. All the advice on countless occasions from his wife, brother and Father, telling him of his impending doom and downfall if he continues in huge borrowing both from banks and individuals for donation, just for public applause, fall on deaf ears. Sooner than later, Uloko gets caught in the web of hypertension resulting from the huge overhang of debts and his failed attempt to use Nweke for money-making ritual. All these eventually lead to his untimely death.

\section{WORK CITED}

Okoye, Ifeoma. Men Without Ears. Mageb Printers Ltd., 1984. Print. 